\title{
Biogeographic distribution of three phylotypes (T1, T2 and T6) of Ammonia (foraminifera, Rhizaria) around Great Britain: new insights from combined molecular and morphological recognition
}

\author{
Julien Richirt ${ }^{1}$, Magali Schweizer ${ }^{1}$, Aurélia Mouret $^{1}$, Sophie Quinchard ${ }^{1}$, Salha A. Saad ${ }^{2}$, \\ Vincent M. P. Bouchet ${ }^{3}$, Christopher M. Wade ${ }^{2}$, and Frans J. Jorissen ${ }^{1}$ \\ ${ }^{1}$ UMR 6112 LPG-BIAF Recent and Fossil Bio-Indicators, University of Angers, \\ University of Nantes, 2 Boulevard Lavoisier, 49045 Angers, France \\ ${ }^{2}$ School of Life Sciences, University of Nottingham, University Park, Nottingham, NG7 2RD, UK \\ ${ }^{3}$ Univ. Lille, CNRS, Univ. Littoral Côte d'Opale, UMR 8187, LOG, Laboratoire d'Océanologie et \\ de Géosciences, Station Marine de Wimereux, 59000, Lille, France \\ Correspondence: Julien Richirt (richirt.julien@gmail.com)
}

Received: 15 December 2020 - Revised: 13 April 2021 - Accepted: 26 April 2021 - Published: 7 June 2021

\begin{abstract}
Ammonia is one of the most widespread foraminiferal genera worldwide. Three phylotypes (Ammonia sp. T1, T2 and T6), commonly encountered in the northeast Atlantic, are usually associated with the morphospecies Ammonia tepida. The biogeographic distribution of these three types was previously investigated in coastal environments around Great Britain based on genetic assignations. A new method was recently developed to recognize these three phylotypes based on morphological criteria (i.e. pore size and suture elevation on spiral side), avoiding the need to use molecular analyses to identify them. The results presented here allow us to validate the consistency of the morphometric determination method but also to define more precisely the pore size variability of each of the three phylotypes, which is a main criterion for their recognition. Moreover, these results, combined with earlier molecular and morphological data, enable us to refine the biogeographic distribution previously established by genetic analyses alone. The biogeographical distribution pattern presented here supports the putatively invasive character of Ammonia sp. T6, by suggesting that this phylotype is currently spreading out over large areas and is supplanting autochthonous phylotypes (T1 and T2) along the coastlines of the British Isles and northern France. In fact, only the southwest coast of England and Ireland and the northwest coast of France have not been colonized by Ammonia sp. T6 yet. Our results also suggest that within the areas colonized by phylotype T6, T2 may find refuges in the inner parts of estuaries. We further suggest that the absence of Ammonia sp. T6 in the western part of the English Channel may be explained by the general surface current circulation pattern, which impedes further expansion. The high reliability of the determination method of phylotypes T1, T2 and T6 based on morphology also allows us to quickly generate large datasets for sub-recent and fossil material. This new method will make it possible to gain an understanding of the ecological differences between the three phylotypes and of the historical changes in their distribution patterns (for example due to changing anthropogenic factors). Finally, it will allow us to confirm or invalidate the putative invasive character of phylotype T6.
\end{abstract}




\section{Introduction}

Discovered in the 18th century, foraminifera are unicellular eukaryotes with a very abundant fossil record, and consequently, they have been widely used for biostratigraphy and palaeoreconstructions (e.g. Sen Gupta, 2003; Jones, 2014). For example, the biogeochemistry of their shells is largely used in palaeoceanographic studies to evaluate conditions of the past oceans related to climate change (see Katz et al., 2010 , for an overview). The fact that foraminifera represent a very valuable tool in palaeoecological reconstructions and more recently also in bio-monitoring of recent ecosystems (Schönfeld et al., 2012) has led to an increased interest in their ecology during the second half of the 20th century.

Among foraminifera, Ammonia is one of the most widespread genera that occur from temperate to tropical regions, in shallow marine as well as estuarine ecosystems. In view of its apparently large tolerance to different types of environmental stress (e.g. Bradshaw, 1957; Alve, 1995; Bouchet et al., 2007; Geslin et al., 2014), this genus is an important tool for palaeoecological reconstructions and biomonitoring of coastal ecosystems. However, Ammonia suffers from taxonomical uncertainties, since traditional taxonomy (based on morphological criteria, i.e. morphospecies) and molecular identification (based on DNA sequences, i.e. phylotype) often give contradictory evidence and are sometimes difficult to reconcile (e.g. Holzmann and Pawlowski, 1997; Hayward et al., 2004; Bird et al., 2020). A part of the problem is the fact that for many morphospecies, the type material is lost and first descriptions are too imprecise to allow comparison with detailed morphometric measurements, such as with pore size data (Hayward et al., 2004; Petersen et al., 2016; Richirt et al., 2019a). In addition, some of the commonly used morphospecies, such as Ammonia tepida or Ammonia beccarii, represent a mixture of different phylotypes, which are now regarded as separate species (Pawlowski et al., 1995; Holzmann et al., 1996; Holzmann, 2000; Langer and Leppig, 2000; Hayward et al., 2004; Schweizer et al., 2011a, b; Hayward et al., 2019).

In the northeast Atlantic, five Ammonia phylotypes are frequently encountered, which have been named T1, T2, T3, T6 and T15 (Hayward et al., 2004; Bird et al., 2020). Phylotypes T3 and T15 are easily distinguishable from the other three (T1, T2 and T6; Hayward et al., 2004; Schweizer et al., 2011a; Bird et al., 2020) and are usually associated with the more ornamented Ammonia "beccarii" morphospecies complex. Phylotypes T1, T2 and T6 are more difficult to discriminate because they are morphologically very close; they are commonly associated with the less ornamented Ammonia "tepida" morphospecies complex.

Here we will consider only phylotypes T1, T2 and T6, which are very common in intertidal areas of the northeast Atlantic. Until recently, their morphological discrimination was difficult, and knowledge of their distribution in this area, which required molecular identification, was restricted to a limited number of specimens and sites (e.g. Holzmann and Pawlowski, 2000; Hayward et al., 2004; Pawlowski and Holzmann, 2008; Schweizer et al., 2011b; Saad and Wade, 2016; Bird et al., 2020). Recently, Richirt et al. (2019a) described a new method to distinguish between T1, T2 and $\mathrm{T} 6$ on the basis of morphological criteria. Consequently, as molecular analysis is no longer needed, it is now possible to quickly determine morphologically large numbers of specimens.

The biogeography of phylotypes $\mathrm{T} 1, \mathrm{~T} 2$ and $\mathrm{T} 6$ in the northeast Atlantic area was earlier investigated on the basis of molecular data in the Wadden Sea and Baltic Sea (Schweizer et al., 2011b) and along the coastline of the British Isles (Saad and Wade, 2016; Bird et al., 2020). However, no clear pattern emerged from these studies, with all three phylotypes inhabiting contrasting coastal ecosystems such as shallow marine, intertidal and subtidal, estuarine and salt marsh environments as well as harbours (Schweizer et al., 2011b; Saad and Wade, 2016; Bird et al., 2020). Consequently, the factors controlling their distribution are still not fully understood.

This study proposes to verify the reliability of the morphometric discrimination method developed in Richirt et al. (2019a) by comparing it with molecular identification on an independent dataset, which was not used to develop the morphometric method. Our first aim is to apply the morphometric criteria proposed by Richirt et al. (2019a) to discriminate between T1, T2 and T6 on the specimens that were described and identified molecularly by Saad and Wade (2016). In the case of discrepancies between the results of the different assignment methods (molecular versus morphometric), the possible reasons for these inconsistencies will be investigated. Our second aim is to use this new morphometric dataset to better constrain the variability of the average pore size for each of the three phylotypes, as described by Richirt et al. (2019a), which is one of the two essential parameters used to discriminate between them. The final aim of this study is to re-analyse the biogeographic distribution pattern of the three phylotypes around the British Isles. In order to do this, we expanded the dataset as much as possible, by including (1) the morphometric determinations of 137 specimens earlier identified by genetic analyses from 17 of the 19 sites in Saad and Wade (2016) and (2) the molecular data for 116 supplementary specimens, sampled at eight additional sites in the English Channel, the Netherlands and in northern France. This final merged dataset includes 25 sampling sites from Great Britain, Ireland, the Netherlands and northern France. Finally, we compare the distribution pattern we obtained with the one from Bird et al. (2020), who investigated the biogeographic distribution of Ammonia phylotypes at many other sites along the northeast Atlantic margin. 


\section{Material and method}

In this study, several datasets will be used, some of them already published, others are new. In the next paragraphs, we will briefly present each of them.

\subsection{Molecular and morphometric investigation of the specimens studied by Saad and Wade (2016)}

\subsubsection{Sampling and DNA sequencing}

The specimens investigated morphometrically here have been studied earlier by Saad and Wade (2016) using molecular methods. Saad and Wade (2016) present a detailed description of the sampling procedure (including the general environmental characteristics of the sampling sites) and the analytical protocol used for molecular identification. Thanks to their non-destructive DNA extraction procedure, the tests of almost all specimens were preserved and could be used for morphometric analyses. Except for two sites from the original publication (South Queensferry and Brancaster Staithe - low marsh), for which the specimens were no longer available, only few individuals were broken or lost. In total, 137 of the 162 specimens which were originally sequenced could be investigated morphometrically (Tables 1 and S1 in the Supplement).

\subsubsection{SEM imaging and morphometric measures}

For all available 137 individuals, we acquired scanning electron microscopy (SEM) overview images of the spiral side as well as detailed images of the penultimate chamber (at $1000 \times$ magnification). These images were used to document the pore size and the suture elevation in the central part of the test, respectively (Plate S1). Pore size measurements were performed following the method of Petersen et al. (2016). These two criteria allow discriminating between phylotypes T1, T2 and T6 with a success rate of $>92 \%$ (Richirt et al., 2019a). In practice, the morphological criteria were hierarchized according to the following steps depicted in the flow chart in Fig. 1:

1. If the average pore diameter is $\leq 1.4 \mu \mathrm{m}$, the specimen is a $\mathrm{T} 2$. If the average pore diameter is $>1.4 \mu \mathrm{m}$, go to (2).

2. If the sutures in the central part of the spiral side are raised (elevated), the specimen is a $\mathrm{T} 1$; if the sutures are flush, the specimen is a T6. If this characteristic is not visible (damaged specimen) or ambiguous, go to (3).

3 . If the average pore diameter is $>2.4 \mu \mathrm{m}$, the specimen is a T6. If the average pore diameter is comprised of between $1.4 \mu \mathrm{m}$ and $2.4 \mu \mathrm{m}$, go to (4).

4. If the number of chamber(s) with incised sutures in the last whorl on the spiral side is $>2$, the specimen is a
T1. If it is $\leq 2$, it is not possible to assign the specimen unambiguously to a phylotype.

When the use of the main criteria (1) and (2) is not sufficient (for example when the test is too damaged), additional criteria (3) and (4) are applied. In some very rare cases in which this checklist does not yield a conclusive response, phylotype assignation is impossible. The morphological identifications obtained were then compared with the molecular identifications made for the same specimens by Saad and Wade (2016).

\subsection{The AMTEP project dataset}

In order to extend our dataset, we included 116 individuals which were sampled and sequenced from five sites along the French north coast (i.e. Authie estuary, Seine estuary, St. Vaast-La-Hougue, Ouistreham (Orne estuary) and Rade de Brest) and three from the Netherlands (Biezelingse Ham, Grevelingen and Veerse Meer). These specimens were collected in the context of the CNRS EC2CO-LEFE project AMTEP. All specimens were individually imaged with SEM, destroyed for DNA extraction, amplified and sequenced as in Richirt et al. (2019a). The sequences were aligned and compared with a set of sequences previously identified as phylotypes T1, T2 and T6 published on GenBank (https: //www.ncbi.nlm.nih.gov/genbank/, last access: 3 June 2021).

\subsection{Dataset of Bird et al. (2020)}

In order to see how the distribution patterns we obtain fit with the larger-scale picture based on molecular identification, we included data from 16 sampled locations by Bird et al. (2020). These authors investigated the distribution of phylotypes T1, T2A, T2B, T3S, T3V (two sub-phylotypes belonging to T3) and T15. Because the morphometric method does not allow us to discriminate between T2A and T2B subphylotypes yet, we merged them for further interpretation, in order to obtain results comparable with our data.

Finally, we did not consider T3S, T3V and T15 in this study. The data for the remaining phylotypes are reproduced in Table 2.

\section{Results}

\subsection{Morphometric identification of the specimens studied by Saad and Wade (2016)}

Of the 137 specimens published by Saad and Wade (2016) which could be analysed molecularly as well as morphologically, the first two morphological criteria (pore diameter and the suture elevation on the spiral side) were sufficient to reliably assign 135 individuals to a phylotype. Criterion (3) of the procedure described in Fig. 1 was only used for one individual (5A-15) because the central part of the spiral side was damaged. Finally, only one specimen could not be assigned on the basis of morphological criteria (Pem-140) because the 
Table 1. Sites, site IDs, geographic coordinates and number of individuals which were identified genetically (from Saad and Wade, 2016) and morphometrically (this study).

\begin{tabular}{|c|c|c|c|c|c|}
\hline Site & Site ID & Latitude & Longitude & $\begin{array}{r}N \text { individuals } \\
\text { genotyped } \\
\text { (Saad and Wade, } \\
2016)\end{array}$ & $\begin{array}{r}N \text { individuals } \\
\text { morphologically } \\
\text { investigated } \\
\text { (this study) }\end{array}$ \\
\hline Bangor & Ban & $53^{\circ} 14^{\prime} 2.41^{\prime \prime} \mathrm{N}$ & $4^{\circ} 7^{\prime} 4.26^{\prime \prime} \mathrm{W}$ & 5 & 4 \\
\hline Barmouth & Bar & $52^{\circ} 43^{\prime} 17.26^{\prime \prime} \mathrm{N}$ & $4^{\circ} 2^{\prime} 27.43^{\prime \prime} \mathrm{W}$ & 10 & 10 \\
\hline Barrow-in-Furness & $\mathrm{BIF}$ & $54^{\circ} 5^{\prime} 24.16^{\prime \prime} \mathrm{N}$ & $3^{\circ} 14^{\prime} 29.61^{\prime \prime} \mathrm{W}$ & 9 & 9 \\
\hline Barton-upon-Humber & Hull & $53^{\circ} 41^{\prime} 50.86^{\prime \prime} \mathrm{N}$ & $0^{\circ} 26^{\prime} 40.08^{\prime \prime} \mathrm{W}$ & 9 & 9 \\
\hline Brancaster Staithe (high marsh) & $4 \mathrm{~A}$ & $52^{\circ} 58^{\prime} 11.78^{\prime \prime} \mathrm{N}$ & $0^{\circ} 40^{\prime} 05.05^{\prime \prime} \mathrm{E}$ & 8 & 7 \\
\hline Brancaster Staithe (low marsh) & $1 \mathrm{~A}$ & $52^{\circ} 58^{\prime} 6.76^{\prime \prime} \mathrm{N}$ & $0^{\circ} 40^{\prime} 5.08^{\prime \prime} \mathrm{E}$ & 10 & 0 \\
\hline Braunton & Brs & $51^{\circ} 5^{\prime} 55.09^{\prime \prime} \mathrm{N}$ & $4^{\circ} 9^{\prime} 52.15^{\prime \prime} \mathrm{W}$ & 10 & 10 \\
\hline Burnham Overy Staithe & $2 \mathrm{~A}$ & $52^{\circ} 57^{\prime} 55.74^{\prime \prime} \mathrm{N}$ & $0^{\circ} 44^{\prime} 48.51^{\prime \prime} \mathrm{E}$ & 10 & 10 \\
\hline Galmpton & Bix & $50^{\circ} 23^{\prime} 31.53^{\prime \prime} \mathrm{N}$ & $3^{\circ} 34^{\prime} 31.15^{\prime \prime} \mathrm{W}$ & 8 & 4 \\
\hline Hambleton & Ham & $53^{\circ} 52^{\prime} 40.15^{\prime \prime} \mathrm{N}$ & $2^{\circ} 57^{\prime} 52.46^{\prime \prime} \mathrm{W}$ & 2 & 2 \\
\hline Lymington & LM & $50^{\circ} 45^{\prime} 16.36^{\prime \prime} \mathrm{N}$ & $1^{\circ} 31^{\prime} 39.34^{\prime \prime} \mathrm{W}$ & 10 & 10 \\
\hline Pembroke Dock & Pem & $51^{\circ} 41^{\prime} 59.66^{\prime \prime} \mathrm{N}$ & $4^{\circ} 55^{\prime} 14.72^{\prime \prime} \mathrm{W}$ & 9 & 9 \\
\hline Pen Clawdd & Lan & $51^{\circ} 38^{\prime} 36.28^{\prime \prime} \mathrm{N}$ & $4^{\circ} 6^{\prime} 20.18^{\prime \prime} \mathrm{W}$ & 10 & 10 \\
\hline Queenborough & Que & $51^{\circ} 25^{\prime} 1.47^{\prime \prime} \mathrm{N}$ & $0^{\circ} 44^{\prime} 21.15^{\prime \prime} \mathrm{E}$ & 9 & 11 \\
\hline Severn Beach & SB & $51^{\circ} 33^{\prime} 17.99^{\prime \prime} \mathrm{N}$ & $2^{\circ} 40^{\prime} 11.37^{\prime \prime} \mathrm{W}$ & 8 & 6 \\
\hline Shoreham-by-Sea & Sho & $50^{\circ} 49^{\prime} 49.04^{\prime \prime} \mathrm{N}$ & $0^{\circ} 16^{\prime} 30.79^{\prime \prime} \mathrm{W}$ & 10 & 10 \\
\hline South Queensferry & Quf & $55^{\circ} 59^{\prime} 34.28^{\prime \prime} \mathrm{N}$ & $3^{\circ} 24^{\prime} 38.18^{\prime \prime} \mathrm{W}$ & 6 & 0 \\
\hline St Osyth & IPS & $51^{\circ} 47^{\prime} 54.83^{\prime \prime} \mathrm{N}$ & $1^{\circ} 3^{\prime} 50.32^{\prime \prime} \mathrm{E}$ & 9 & 9 \\
\hline \multirow[t]{2}{*}{ Thornham } & $5 \mathrm{~A}$ & $52^{\circ} 57^{\prime} 59.35^{\prime \prime} \mathrm{N}$ & $0^{\circ} 34^{\prime} 20.09^{\prime \prime} \mathrm{E}$ & 10 & 7 \\
\hline & & & Total & 162 & 137 \\
\hline
\end{tabular}

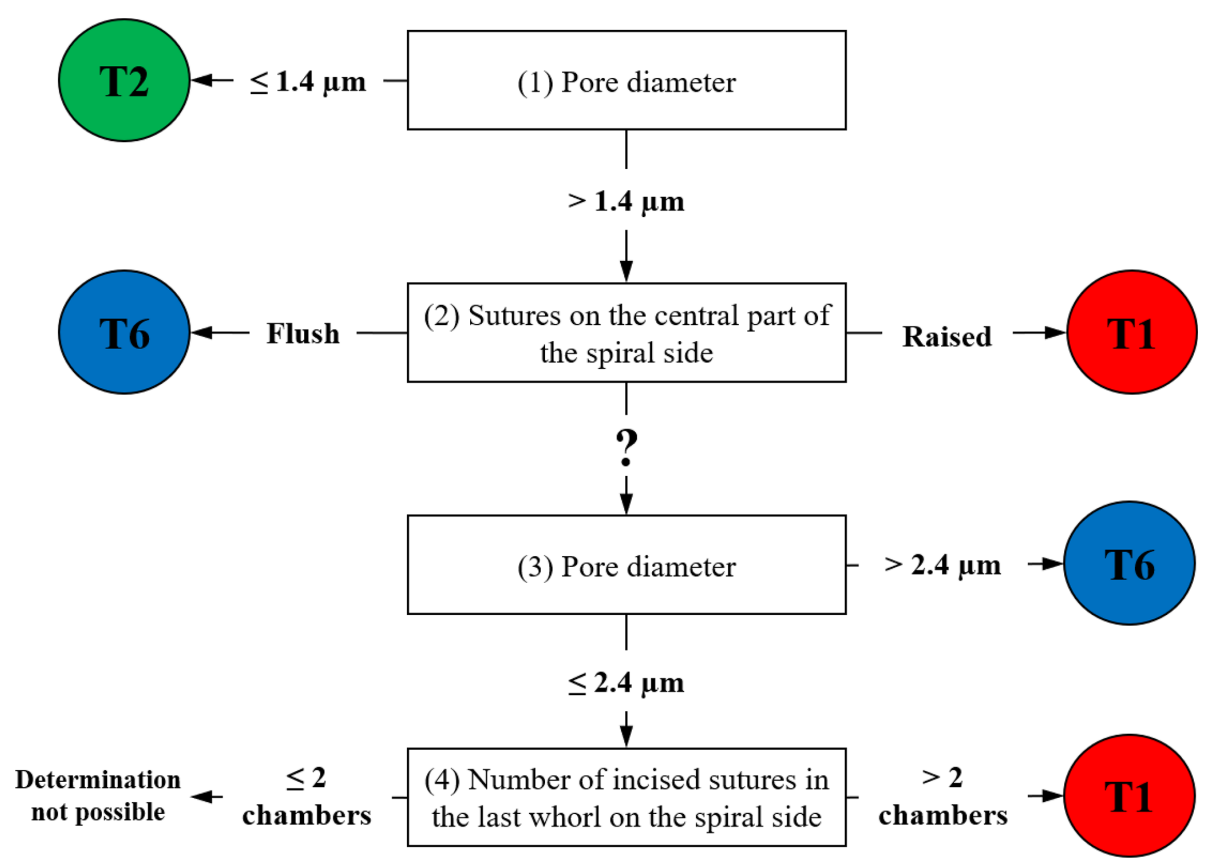

Figure 1. Dichotomous procedure to discriminate between T1, T2 and T6. 
Table 2. Location, geographic coordinates and number of individuals genetically identified as T1, T2A, T2B and T6 for the 16 sites of Bird et al. (2020).

\begin{tabular}{lllrrrrr}
\hline Site & Latitude & Longitude & T1 & T2A & T2B & T6 & Total \\
\hline Cromarty (CR) & $57^{\circ} 40^{\prime} 45.59^{\prime \prime} \mathrm{N}$ & $04^{\circ} 02^{\prime} 28.12^{\prime \prime} \mathrm{W}$ & 0 & 1 & 0 & 0 & 1 \\
Loch Sunart (SU) & $56^{\circ} 39^{\prime} 56.80^{\prime \prime} \mathrm{N}$ & $05^{\circ} 52^{\prime} 02.10^{\prime \prime} \mathrm{W}$ & 1 & 0 & 0 & 0 & 1 \\
Dunstaffnage (DF) & $56^{\circ} 27^{\prime} 06.1^{\prime \prime} \mathrm{N}$ & $05^{\circ} 27^{\prime} 27.9^{\prime \prime} \mathrm{W}$ & 1 & 0 & 0 & 0 & 1 \\
Torry Bay (TB) & $56^{\circ} 03^{\prime} 28.3^{\prime \prime} \mathrm{N}$ & $03^{\circ} 35^{\prime} 02.5^{\prime \prime} \mathrm{W}$ & 0 & 0 & 0 & 8 & 8 \\
Cramond (Cd) & $55^{\circ} 58^{\prime} 54.2^{\prime \prime} \mathrm{N}$ & $03^{\circ} 17^{\prime} 56.5^{\prime \prime} \mathrm{W}$ & 0 & 0 & 0 & 52 & 52 \\
Loch na Cille (LK) & $55^{\circ} 57^{\prime} 36.00^{\prime \prime} \mathrm{N}$ & $05^{\circ} 41^{\prime} 24.00^{\prime \prime} \mathrm{W}$ & 0 & 13 & 0 & 0 & 13 \\
Whiterock (WR) & $54^{\circ} 29^{\prime} 05.42^{\prime \prime} \mathrm{N}$ & $05^{\circ} 39^{\prime} 12.58^{\prime \prime} \mathrm{W}$ & 0 & 18 & 0 & 0 & 18 \\
Den Oever (F) & $52^{\circ} 56^{\prime} 24.8^{\prime \prime} \mathrm{N}$ & $05^{\circ} 01^{\prime} 30.6^{\prime \prime} \mathrm{E}$ & 0 & 0 & 0 & 1 & 1 \\
Norfolk (NF) & $52^{\circ} 49^{\prime} 02.41^{\prime \prime} \mathrm{N}$ & $00^{\circ} 21^{\prime} 46.16^{\prime \prime} \mathrm{E}$ & 0 & 1 & 0 & 30 & 31 \\
Laugharne Castle (LC) & $51^{\circ} 46^{\prime} 12.00^{\prime \prime} \mathrm{N}$ & $04^{\circ} 27^{\prime} 00.00^{\prime \prime} \mathrm{W}$ & 0 & 0 & 0 & 2 & 2 \\
Grevelingen (Gv) & $51^{\circ} 44^{\prime} 50.04^{\prime \prime} \mathrm{N}$ & $03^{\circ} 53^{\prime} 24.06^{\prime \prime} \mathrm{E}$ & 0 & 0 & 0 & 2 & 2 \\
Cork (CK) & $51^{\circ} 38^{\prime} 29.40^{\prime \prime} \mathrm{N}$ & $08^{\circ} 45^{\prime} 44.50^{\prime \prime} \mathrm{W}$ & 2 & 0 & 28 & 0 & 30 \\
Cardiff (CF) & $51^{\circ} 29^{\prime} 25.40^{\prime \prime} \mathrm{N}$ & $03^{\circ} 07^{\prime} 19.50^{\prime \prime} \mathrm{W}$ & 0 & 0 & 0 & 20 & 20 \\
Dartmouth (DM) - upper shore & $50^{\circ} 21^{\prime} 04.84^{\prime \prime} \mathrm{N}$ & $03^{\circ} 34^{\prime} 11.33^{\prime \prime} \mathrm{W}$ & 0 & 6 & 0 & 0 & 6 \\
Dartmouth (DM) - mid shore & $50^{\circ} 21^{\prime} 04.84^{\prime \prime} \mathrm{N}$ & $03^{\circ} 34^{\prime} 11.33^{\prime \prime} \mathrm{W}$ & 2 & 12 & 0 & 0 & 14 \\
Dartmouth (DM) - lower shore & $50^{\circ} 21^{\prime} 04.84^{\prime \prime} \mathrm{N}$ & $03^{\circ} 34^{\prime} 11.33^{\prime \prime} \mathrm{W}$ & 2 & 49 & 0 & 0 & 51 \\
\hline & & $T^{\prime}{ }^{\prime}$ & 8 & 100 & 28 & 115 & 251 \\
\hline
\end{tabular}

test was too heavily damaged. Among the 136 specimens identified morphologically, T6 was the dominant phylotype with 94 individuals (69\%), followed by T2 with 28 individuals $(21 \%)$, whereas $\mathrm{T} 1$ was least represented by 14 individuals $(10 \%)$.

The correspondence between the genetic identifications of Saad and Wade (2016) and the morphological discriminations performed here is shown in Fig. 2. Of the 136 specimens, 117 were assigned identically $(86 \%)$ by the molecular and morphological methods, whereas 19 (14\%) were assigned differently by both methods. Fourteen of these nineteen specimens came from two sites only: Thornham (5A) and Shoreham-by-Sea (Sho).

At Thornham, the seven specimens analysed morphologically (5A-15, 5A-34, 5A-37, 5A-38, 5A-39, 5A-40 and 5A62) were all determined as T6; their average pore diameter $(1.91$ to $3.08 \mu \mathrm{m})$ was largely above the empirical upper threshold of T2 of $1.4 \mu \mathrm{m}$, as determined by Richirt et al. (2019a). Six of these specimens were identified genetically as T2 and only one as T6 (5A-15, Fig. 2). At Shorehamby-Sea, 10 specimens were genetically assigned to $\mathrm{T} 6$, but only two specimens (Sho-3 and Sho-8) were identified as such morphologically. Of the remaining eight specimens, seven were determined morphologically as T2 (Sho-2, Sho4, Sho-6, Sho-10, Sho-11, Sho-12 and Sho-13), whereas a single specimen (Sho-7) was determined as T1 (Fig. 2). The average pore size of Sho- $8(1.41 \mu \mathrm{m})$ was very slightly above the threshold value of $1.4 \mu \mathrm{m}$ of Richirt et al. (2019a). In fact, Richirt et al. (2019a) found a range of $0.76-1.35 \mu \mathrm{m}$ for the average pore diameter of $\mathrm{T} 2$, compared to $1.92-3.55 \mu \mathrm{m}$ for T6. The overall appearance of specimen Sho- 8 is typical of T2 (with lunate, non-inflated later chambers; Plate S1 in the

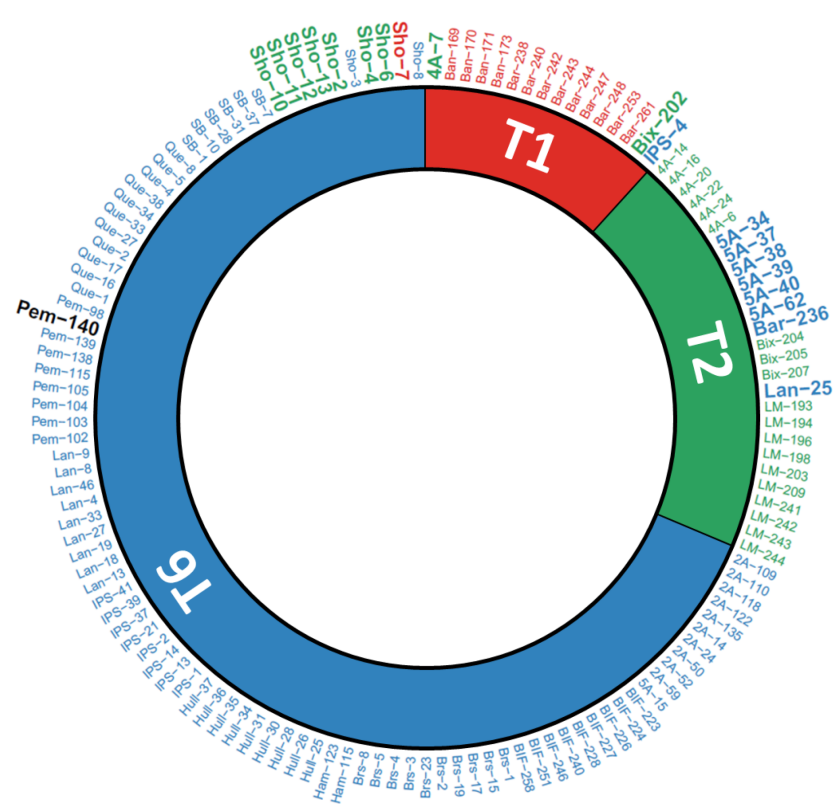

Figure 2. Circular diagram comparing molecular identification (internal part of the diagram, from Saad and Wade, 2016) with morphological determination (external part of the diagram) for the 137 individuals investigated in this study (ordered by molecular identification and their IDs). Red: T1; green: T2; blue: T6. Not determined morphologically: black. Specimens for which molecular and morphological assignations mismatch or for which morphological determination was not possible are indicated in bold with a greater font size. 
Supplement) and rather different from T6 (rectangular, somewhat inflated later chambers). This strongly suggests that the threshold value of $1.4 \mu \mathrm{m}$ proposed by Richirt et al. (2019a) was slightly too low and that specimen Sho- 8 is in reality a $\mathrm{T} 2$.

It is striking to see that the molecular and genetic determinations give almost exactly the opposite results for the two sites: 10 T6 (genetics) at Shoreham-by-Sea versus 7 T6 (morphometry) at Thornham; 8 T2 and 2 T6 (genetics) at Thornham versus 8 T2, 1 T6 and 1 T1 (morphometry, if we consider Sho-8 as a T2) at Shoreham-by-Sea. The most obvious explanation for this would be that the specimens of these two sites have been inverted.

The fact that our SEM images are similar to the light microscope pictures presented in the supplementary fig. 3 of Saad and Wade (2016) suggests that this inversion took place after sequencing and before light microscope pictures were taken.

Such a putative inversion would explain all observed discrepancies (except for the single specimen morphologically determined as $\mathrm{T} 1$ in the Shoreham-by-Sea sample) and restore the high consistency between genetic and morphological assignation methods $(\sim 95 \%)$, in accordance with the rate of successful assignation in Richirt et al. (2019a).

However, because we cannot conclude with certainty that the specimens from the Thornham and Shoreham-by-Sea were inversed after sequencing, we decided to remove them from the dataset before further interpretation. The other five discrepancies concerned isolated specimens from different sites: 4A-7 (Brancaster high marsh), Bix-202 (Galmpton), IPS-4 (St Osyth), Bar-236 (Barmouth) and Lan-25 (Pen Clawdd). In three of the five cases (4A7, IPS-4 and Bar-236), the isolated specimen was genetically identified differently from all other specimens of the considered site, whereas it was morphologically identified as the same phylotype as all other specimens of the considered site.

Figure 3 shows the position and IDs of the mismatching individuals on the graph representing suture elevation and average pore diameter. All data concerning average pore diameter, determination of the suture character (flush or raised), and SEM images of the spiral side and of the penultimate chamber at $1000 \times$ magnification for the 137 specimens investigated in this study are available in Table S1 and Plate S1.

\subsection{The AMTEP project dataset}

Of the 116 sequenced individuals sampled at eight sites from the AMTEP project (Table 3), 26 were part of the 96 specimens used by Richirt et al. (2019a) to develop the morphometric assignment method, and sequences of 10 individuals have already been published in GenBank (Table S2). Seven more individuals, from Lake Grevelingen, presented by Richirt et al. (2020), have also been deposited in the GenBank database (accession numbers MN190684MN190690).
Among the 26 individuals published by Richirt et al. (2019a), 23 were classified similarly by molecular and morphometric methods. The authors argued that three individuals had been incorrectly classified by molecular analysis (Richirt et al., 2019a). Accordingly, we will further use the morphological identification for these three individuals and the molecular assignation for the other specimens of this dataset. Although the sub-phylotypes T2A and T2B were distinguished previously (Tables 3, S2), they have been merged here because it is impossible as yet to discriminate between them morphologically (cryptic species). Phylotype T6 was the only phylotype occurring at Authie estuary (4 individuals, ind. hereafter), Biezelingse Ham (51 ind.), Grevelingen (7 ind.) and in the Seine estuary (32 ind.). Phylotype T2 was the only phylotype found at the Rade de Brest ( 2 ind.). Two sites yielded two phylotypes: at St. Vaast-La-Hougue, a single T1 and three T2 and at the Veerse Meer five T2 and four T6 were found. Ouistreham was the only site where the three phylotypes were found together (five T6, one T1 and one T2).

\section{Discussion}

\subsection{Reliability of the morphometric assignment method}

Of the 119 individuals that Saad and Wade (2016) identified morphologically (not considering the specimens from the Thornham and Shoreham-by-Sea sites), molecular and morphometric analyses yielded the same result for $96 \%$ of the individuals. The difference between both methods concerns five specimens ( $4 \%$ ) coming from five different locations (4A-7, Bix-202, IPS-4, Bar-236 and Lan-25, indicated with their ID number in Fig. 3):

- Specimen 4A-7: Brancaster Staithe high marsh, genotyped as T1, morphologically assigned to T2. This individual has a mean pore diameter of $0.97 \mu \mathrm{m}$, far lower than the observed range of $\mathrm{T} 1(1.51-2.62 \mu \mathrm{m}$ in Richirt et al., 2019a) and flush sutures. This strongly suggests that this specimen is a T2, like all other specimens from this locality, for which genetic and morphometric identification are in agreement.

- Specimen Bix-202: Galmpton, genotyped as T1, morphologically assigned to T2. This individual has a mean pore diameter of $1.25 \mu \mathrm{m}$ (within the range of $\mathrm{T} 2$, slightly below the lower limit of $\mathrm{T} 1$ of $1.4 \mu \mathrm{m}$ ) and flush sutures. In total, six specimens were genotyped as T2 and two as $\mathrm{T} 1$ at this site.

- Specimen IPS-4: St Osyth, genotyped as T1, morphologically assigned to T6. This individual has an average pore diameter of $2.53 \mu \mathrm{m}$ (slightly above the upper limit of $\mathrm{T} 1$ of $2.4 \mu \mathrm{m}$ ) and flush sutures, which are defining morphological traits of T6. The eight other individuals from this site were also morphologically assigned to T6, in agreement with molecular identification. 


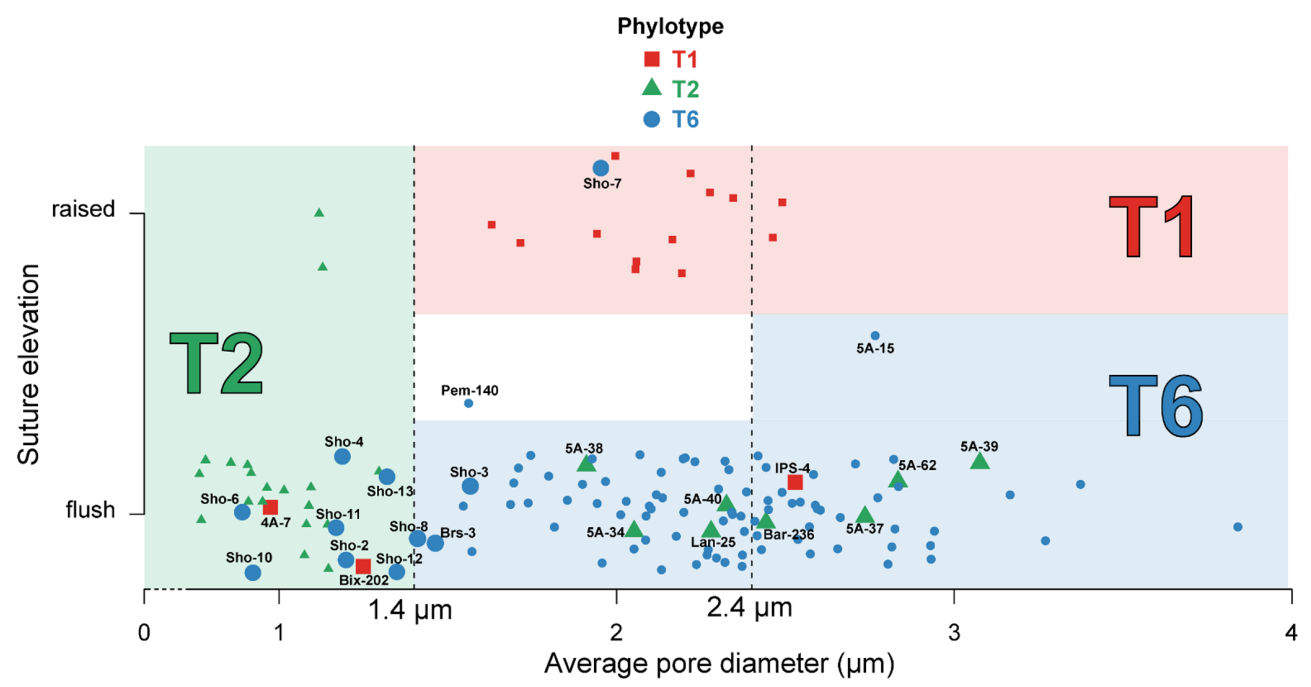

Figure 3. Average pore diameter $(\mu \mathrm{m})$ and suture elevation (flush or raised) for the 137 individuals investigated morphologically. Individuals genotyped as T1 (red squares), T2 (green triangles) and T6 (blue circles) are represented in the graph which separates the three phylotypes on the basis of their average pore diameter and suture elevation following Richirt et al. (2019a) (red area for T1, green area for T2 and blue area for T6). Individuals for which genetic and morphological identification are mismatching, or are discussed in the text, are represented by bigger marks and associated with their IDs (see Supplement). Pem-140 was too damaged to be morphologically determined regarding the suture elevation (white area); 5A-15 is the only specimen for which we used criterion (3) of the dichotomous procedure indicated in Fig. 1. The (random) vertical dispersion was artificially added in order to better visualize all specimens separately. Vertical dotted lines represent the thresholds to discriminate between the phylotypes as determined by Richirt et al. (2019a).

Table 3. Location, geographic coordinates and number of individuals genetically identified as T1, T2A, T2B and T6 at the sites of the AMTEP project.

\begin{tabular}{lllrrrrr}
\hline Localization & Latitude & Longitude & T1 & T2a & T2b & T6 & Total \\
\hline Authie estuary & $50^{\circ} 22^{\prime} 23.80^{\prime \prime} \mathrm{N}$ & $1^{\circ} 35^{\prime} 44.00^{\prime \prime} \mathrm{E}$ & 0 & 0 & 0 & 4 & 4 \\
Biezelingse Ham & $51^{\circ} 26^{\prime} 53.40^{\prime \prime} \mathrm{N}$ & $3^{\circ} 55^{\prime} 49.79^{\prime \prime} \mathrm{E}$ & 0 & 0 & 0 & 51 & 51 \\
Grevelingen & $51^{\circ} 44^{\prime} 50.04^{\prime \prime} \mathrm{N}$ & $3^{\circ} 53^{\prime} 24.06^{\prime \prime} \mathrm{E}$ & 0 & 0 & 0 & 7 & 7 \\
Ouistreham & $49^{\circ} 16^{\prime} 16.40^{\prime \prime} \mathrm{N}$ & $0^{\circ} 14^{\prime} 12.20^{\prime \prime} \mathrm{W}$ & 1 & 0 & 1 & 5 & 7 \\
Rade de Brest & $48^{\circ} 24^{\prime} 13.10^{\prime \prime} \mathrm{N}$ & $4^{\circ} 21^{\prime} 16.00^{\prime \prime} \mathrm{W}$ & 0 & 2 & 0 & 0 & 2 \\
Seine estuary & $49^{\circ} 26^{\prime} 31.30^{\prime \prime} \mathrm{N}$ & $0^{\circ} 16^{\prime} 25.20^{\prime \prime} \mathrm{E}$ & 0 & 0 & 0 & 32 & 32 \\
St. Vaast-La-Hougue & $49^{\circ} 34^{\prime} 38.60^{\prime \prime} \mathrm{N}$ & $1^{\circ} 16^{\prime} 38.80^{\prime \prime} \mathrm{W}$ & 1 & 3 & 0 & 0 & 4 \\
Veerse Meer & $51^{\circ} 33^{\prime} 12.24^{\prime \prime} \mathrm{N}$ & $3^{\circ} 52^{\prime} 25.34^{\prime \prime} \mathrm{E}$ & 0 & 5 & 0 & 4 & 9 \\
\hline & & Total & 2 & 10 & 1 & 103 & 116 \\
\hline
\end{tabular}

- Specimen Lan-25: Pen Clawdd, genotyped as T2, morphologically assigned to $\mathrm{T} 6$. The mean pore diameter of Lan-25 $(2.28 \mu \mathrm{m})$ is far too high for a T2 $(\leq 1.4 \mu \mathrm{m})$, and additionally, the sutures in the central part of the spiral side are flush, strongly suggesting that this is a T6. At this location, the other nine specimens were all identified as $\mathrm{T} 6$ by molecular and morphometric methods.

- Specimen Bar-236: Barmouth, genotyped as T2, morphologically assigned to T6. Bar-236 both has a mean pore diameter of $2.44 \mu \mathrm{m}$, far higher than the $\mathrm{T} 2$ range $(\leq 1.4 \mu \mathrm{m})$, and flush sutures, again strongly suggesting that it is a T6 rather than a $\mathrm{T} 2$.
Erroneous morphological assignments exist, especially in the case of damaged specimens, explaining why the rate of corresponding identification between molecular and morphological methods is not $100 \%$ (Richirt et al., 2019a). However, incorrect identification may also happen with molecular determination. Here, different causes are possible, such as (1) environmental contamination, which is impossible to control (presence of exogenous material on and/or in the shell, e.g. propagules from another phylotype, maybe remains of prey if feeding on another phylotype; Hemleben et al., 1989) or (2) laboratory cross-contamination, which cannot be totally eliminated, even in the case of very careful laboratory practice (Weiner et al., 2016). The consequence is that in genetic analyses, occasionally, individual specimens may be deter- 
mined erroneously in a very unpredictable way. In morphological determinations, the problem is different: the available data on pore density and size are very robust, and specimens of a specific phylotype with porosity values far outside the usual range have never been observed. In morphological determinations, the specimens close to the limits between two genotypes may pose problems and may on rare occasions be incorrectly determined. The ultimate consequence is that in some cases (specimens with mean pore diameter values far from the phylotype limit) morphological analyses will be more reliable, whereas in other cases (mean pore diameter values close to the phylotype limit), molecular analyses will be more reliable. The five specimens for which genetic and morphological data differed were interpreted following this reasoning.

For these five specimens, it appears that in three cases (4A7, Lan-25 and Bar-236), the morphological traits are very far from those characterizing the assigned phylotype. For 4A-7 and Lan-25, the morphological determination was the same as the molecular and morphometric determination of all other specimens of the assemblage, which were morphologically always very similar to the individual under discussion. This corroborates our conclusion that in these three cases, the morphological determination is correct.

For the remaining two specimens (Bix-202 and IPS-4) the situation is less clear. In both cases, the pore diameter is close to the limit between the two concerned phylotypes so that the morphological attribution is also partly based on the flush aspect of the dorsal sutures. In these two cases, it is not clear whether the genetic or morphological assignment is correct.

\subsection{Ranges of average pore size diameter of phylotypes $\mathrm{T} 1, \mathrm{~T} 2$ and $\mathrm{T} 6$}

The range of measured average pore diameter for the 21 individuals of $\mathrm{T} 2$ was very close to that given by Richirt et al. (2019a; $0.76-1.30 \mu \mathrm{m}$ for this study compared to $0.77-$ $1.32 \mu \mathrm{m})$. Also, for the 13 specimens of $\mathrm{T} 1$, the range of average pore diameter was very close to the observations of Richirt et al. (2019a): 1.63-2.49 $\mu \mathrm{m}$ in this study compared to $1.51-2.62 \mu \mathrm{m}$. Finally, the range of observed mean pore diameters for T6 (1.46 to $3.84 \mu \mathrm{m})$ was larger than the range described by Richirt et al. (2019a; $1.92-3.55 \mu \mathrm{m})$.

Our present data show that the range of observed mean pore diameter of T6 was underestimated in Richirt et al. (2019a). This means that the upper limit of average pore size of T2 $(1.32 \mu \mathrm{m})$ and the lower limit for T6 $(1.46 \mu \mathrm{m})$ are relatively close. A study of larger numbers of specimens could eventually result in a small overlap. In this case, it may then be useful to consider the general test shape as an additional criterion. In general, typical T2 specimens show lunate, non-inflated later chambers and differ from typical T6 specimens that show rectangular, somewhat inflated later chambers (Plate S1). This observation confirms that more morphometric studies are necessary to better define the ranges of pore size for the different phylotypes, if possible in different environmental settings.

\subsection{Geographical distribution of T1, T2 and T6}

In this section, we will present an update of the distributional data for the three investigated phylotypes. We will base our inventory both on genetic and morphometric determinations, but in the case of discrepancy concerning single specimens, we will favour morphological determinations.

Figure 4 presents a composite map of the three datasets aggregating (1) the 119 specimens determined here by the morphometric method, (2) the 116 individuals investigated in the context of the AMTEP project and (3) the 251 individuals investigated by Bird et al. (2020). Together, the three datasets represent 486 individuals of 36 different sites (the three sampled sites from Dartmouth in Bird et al. (2020) are regarded as a single location, and the Grevelingen site is present in both AMTEP and Bird et al. (2020) datasets). These 486 individuals account for 303 specimens belonging to phylotype T6, 160 to phylotype T2 (with T2A and T2B merged) and 23 to phylotype $\mathrm{T} 1$.

Figure 4 presents a highly consistent biogeographical pattern. Phylotype T6 is strongly dominant on the eastern coast of England, on the eastern English Channel coast, as well as in Liverpool Bay and the Bristol Channel. Phylotype T2 is dominant on the western English Channel coast (both on the south coast of England and on the northwest coast of France). It is also dominant at two sites in Ireland and one site in west Scotland, whereas a single individual was genotyped at a site in north Scotland. Furthermore, T2 is also dominant at two isolated sites, where it is surrounded by T6 populations: one on the Norfolk coast (i.e. Brancaster Staithe high marsh) and one in the Netherlands (i.e. Veerse Meer, inner part of the Eastern Scheldt estuary). Finally, phylotype T1 is dominant at two sites in Wales (i.e. Barmouth and Bangor), whereas two single individuals were found at two sites in Scotland. The two sites in Wales are bordered by T6 populations both in the north and south (Liverpool Bay and the Bristol Channel, respectively).

It is interesting to note that the co-occurrence of different phylotypes at the same site is not common; only 8 of the 39 sampled locations show a co-occurrence of at least two phylotypes (Fig. 4). In all cases, one of the phylotypes is strongly dominant. The single exception is the Veerse Meer site in the Netherlands, where T2 and T6 are found in similar proportions (five and four individuals, respectively). Since the three phylotypes are now regarded as separated species (Pawlowski et al., 1995; Holzmann et al., 1996; Holzmann, 2000; Holzmann and Pawlowski, 2000; Langer and Leppig, 2000; Schweizer et al., 2011a, b), it may be expected that their ecological niches are slightly different. This suggests that at each individual site, one of the three phylotypes should be favoured by the local environmental conditions, explaining its strong dominance. 


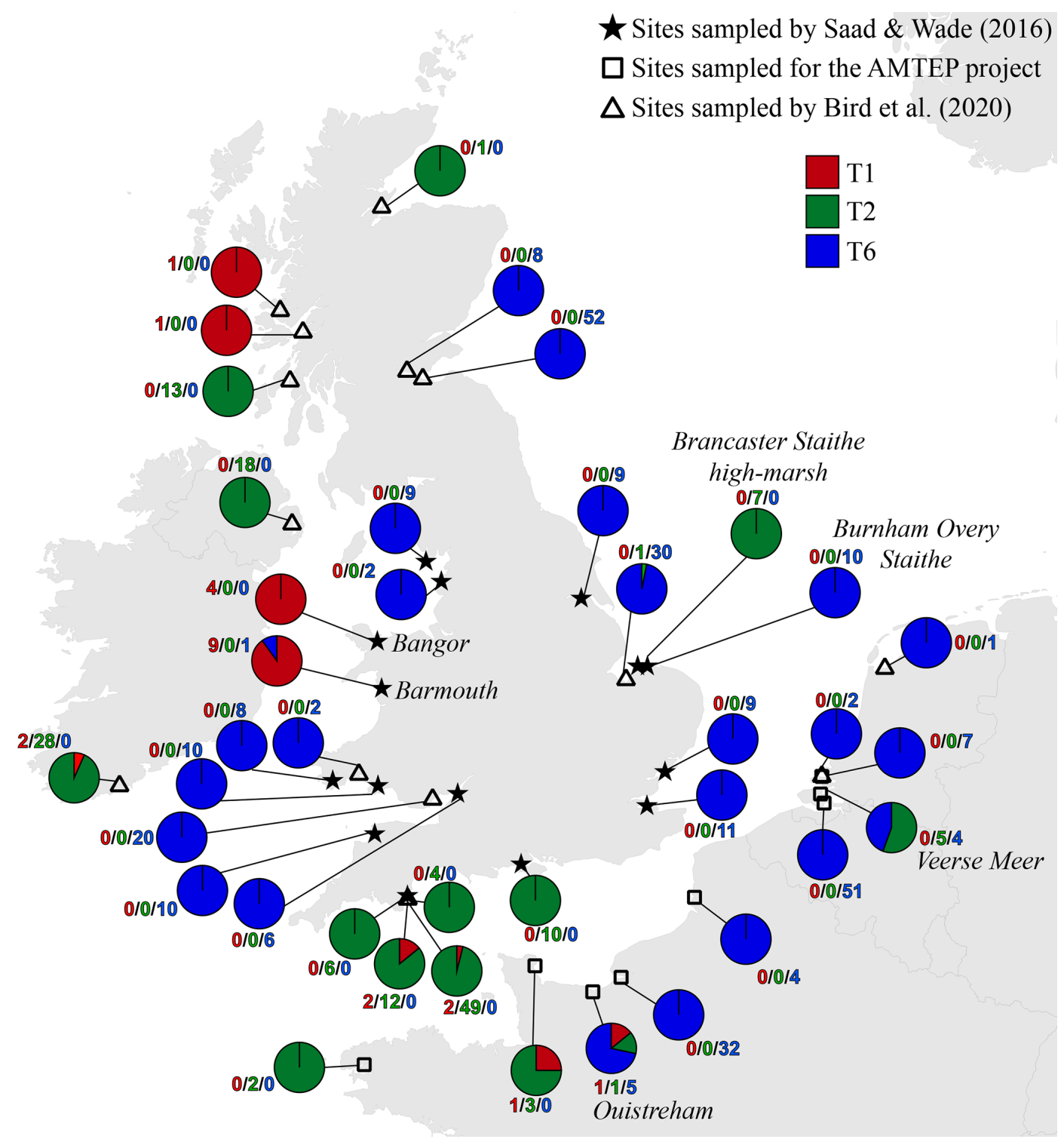

Figure 4. Distribution map showing the number of individuals for the three phylotypes, combining the data from this study (stars, morphological identification of the available individuals from Saad and Wade, 2016), from the AMTEP project (squares, based on genetic identification and morphology for specimens used in Richirt et al., 2019a) and from Bird et al. (2020) (triangles, based on genetic identification). The particular sites discussed in the text later - i.e. Barmouth, Brancaster Staithe high marsh, Ouistreham and Veerse Meer - are indicated in italics.

However, if entire estuaries or marsh systems are considered, the co-occurrence of several phylotypes at different locations appears to be common. This is for example observed at the Brancaster Staithe high marsh (dominated by T2) and the Burnham Overy Staithe site (dominated by T6), both sites belonging to the same marsh system. Other examples are the Vie estuary and the Auray river (Gulf of Morbihan) both on the French Atlantic coast, where both phylotypes T1 and T2 are found, but in different proportions, depending on the exact location in the estuary (Fouet et al., 2021; Schweizer et al., 2021).
At a global scale, phylotype T1 is considered cosmopolitan, whereas T2 seems to be restricted to the North Atlantic (Holzmann and Pawlowski, 2000; Hayward et al., 2004). Concerning T6, because of its disjunct global distribution (i.e. Asia and Europe), it has been suggested that it has its origins in Asia and may be allochthonous in Europe. In fact, T6 arrived around 2000 in the Kiel fjord (Polovodova et al., 2009; Schweizer et al., 2011b) and in Hanö Bay in the Baltic Sea (Bird et al., 2020), where no Ammonia species were present before (Hermelin, 1987; Murray, 2006). It may have been introduced by an anthropogenic vector such as ship bal- 
last water (Pawlowski and Holzmann, 2008), as already hypothesized for Haynesina germanica (Calvo-Marcilese and Langer, 2010), or together with imported Japanese oysters (after mass mortality of local oysters in Europe in the 1960s, Wolff and Reise, 2002).

If phylotype $\mathrm{T} 6$ is indeed invasive, it may be expected that it has spread out progressively and has replaced autochthonous phylotypes $\mathrm{T} 1$ and/or T2 at most sites where it is found now. The fact that "only" $55 \%$ of the sampled sites are dominated by T6 could mean that the autochthonous phylotypes $\mathrm{T} 1$ and $\mathrm{T} 2$ are better adapted to the environmental conditions at some of the remaining sites. For example, the two sites with $\mathrm{T} 2$ populations surrounded by T6-dominated faunas in Brancaster Staithe high marsh and in the Veerse Meer are positioned at higher elevation close to salt marshes (Brancaster Staithe high marsh) or in the inner part of the estuary (Veerse Meer). This suggests that a weaker marine influence is unfavourable for T6. However, this observation seems to contrast with the recent arrival (around 2000) of T6 in the hyposaline Baltic Sea (Polovodova et al., 2009; Schweizer et al., 2011b; Bird et al., 2020). However, the Baltic Sea is also the largest anthropogenically induced hypoxic area in the world (Carstensen et al., 2014), and the success of phylotype T6 in this area could also reflect its larger tolerance of low oxygen concentrations (compared to phylotypes T1 and T2), due to its larger porosity (Richirt et al., 2019a, b, 2020).

Alternatively, the observed pattern could also suggest that the replacement of the autochthonous phylotypes by T6 is not yet finished and that $\mathrm{T} 6$ may further extend its distributional area in the near future.

\subsection{Putative hydrodynamic control on the geographical distribution of Ammonia phylotypes}

Because of their small size and inability of active displacement over large distances, foraminiferal migration will probably mainly depend on propagule dispersal by mesoscale spatial hydrodynamic features (e.g. tidal residual currents, wind-driven currents, gyres; Ellien et al., 2000). These features have earlier been identified as decisive for the transport of microorganisms over long distances (Salomon and Breton, 1993; Bailly du Bois and Dumas, 2005). In the case of benthic foraminifera, reports of their presence in sediment traps (Brunner and Biscaye, 1997, 2003; Kuhnt et al., 2013) and planktonic eDNA samples (Morard et al., 2019) suggest that transport in the water column may be rather common. The fact that foraminiferal propagules may be dormant for several years (Alve and Goldstein, 2010) further increases their dispersal potential. In view of this, it appears that the direction and intensity of bottom as well as water column currents could be a determinant for the transport of foraminiferal propagules away from their source populations.

The English Channel is famous for its strong tidal currents, including currents with a periodicity of the order of 1 week

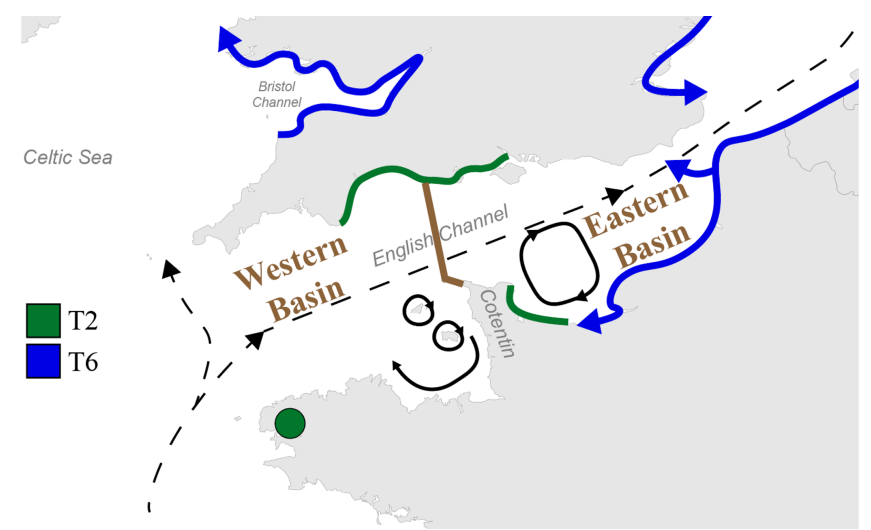

Figure 5. Map displaying the general circulation of water masses in the English Channel. Black dashed arrows represent the residual currents and black plain arrows represent the main gyres in the Channel (Salomon and Breton, 1993; Dupont et al., 2007). The separation between the Western and Eastern Basins of the English Channel is represented by the brown line (from Dauvin, 2012). The putative distributional area of phylotypes T2 and T6 is represented by green and blue lines, respectively. Blue arrows indicate the hypothesized direction of progression of the phylotype T6, with its putative ability to cross the English Channel in the Eastern Basin.

to 1 year (i.e. residual tidal currents, Salomon and Breton, 1993). Although the main water mass circulation through the Channel is northeastward, from the open Atlantic Ocean to the North Sea, numerous secondary gyres generated by tidal currents are present, especially around the Cotentin Peninsula along the French coast, limiting exchanges between the eastern and the western part of the peninsula (Salomon and Breton, 1993; Cugier and Le Hir, 2002).

Previously, the English Channel has been divided into two basins by Dauvin (2012): the Western and the Eastern Basin, with a boundary at the Cotentin Peninsula (Fig. 5). This subdivision was based on differences in general oceanographic characteristics, biological components and human activity. In fact, many studies on the hydrodynamics and larval dispersal in the English Channel show that there is a major biogeographic boundary which strongly limits larvae transport between the areas to the east and west of the Cotentin Peninsula (e.g. Ellien et al., 2000; Lefebvre et al., 2003; Dupont et al., 2003, 2007). Additionally, transport between French and English coasts seems strongly limited in the western part of the English Channel but was shown to occur in the eastern part (Barnay et al., 2003; Lefebvre et al., 2003).

Furthermore, the high hydrodynamics in the English Channel lead to large continuous rocky shores and sandy beach habitats, limiting the distribution of muddy habitats to bays and estuaries, which cover only a small part of the coastlines (Larsonneur et al., 1982; Dauvin, 2015). The resulting fractionated and relatively scarce occurrence of muddy habitats could further limit the westward expansion of Ammonia sp. T6 in the English Channel. A similar distribution pattern 
(i.e. limited to the eastern English Channel) was reported for the invasive Asiatic crab species Hemigrapsus takanoi, which also tends to occupy mud habitats resulting from weak hydrodynamics (Dauvin et al., 2009; Gothland et al., 2014).

If we hypothesize that Ammonia sp. T6 is an invasive phylotype which is still expanding, the major biogeographical boundary in the English Channel, which appears to be related to the overall current pattern, could explain why T6 has not yet colonized the southern English coast and the French western part of the English Channel. The remaining sites dominated by $\mathrm{T} 2$ in the Irish Sea could be the consequence of similar biogeographic barriers (Fig. 5). Evidently, as it is not yet proven that T6 is indeed an invasive exotic phylotype, this hypothesis is still speculative.

\subsection{Limitations of the present study}

\subsubsection{Geographical sampling coverage}

Although the 486 individuals sampled at 36 different sites give a good general overview of the geographical distribution of T1, T2 and T6, it is evident that the sampling coverage is far too limited to allow a detailed analysis of the geographical distribution and ecological preferences of each of the three phylotypes. In fact, the present dataset suffers from two main limitations, which are largely due to the fact that molecular identification is a rather expensive and timeconsuming method:

1. There is often only one sample per estuary, whereas the scarce available data show that in many estuaries, two or even three phylotypes are present, which occupy different parts of the estuary.

2. In most cases, only a few individuals were sampled at each site (rarely more than 10 individuals), which is insufficient to draw firm conclusions about the eventual co-occurrence of two or even three phylotypes at a single sampling site.

Fortunately, now that it has been shown that the three phylotypes can be distinguished by morphometric analysis with a high degree of reliability (about 96\%, Richirt et al., 2019a; results of this study), it has become possible to rapidly generate large amounts of data. The combination with eDNA surveys of the same areas (work in progress, Schweizer et al., 2021) could also speed up data acquisition and rapidly increase geographical coverage. Consequently, the biogeographical patterns presented here will certainly be refined (and where necessary, corrected) in the next few years.

\subsubsection{Temporal scale}

The absolute and relative densities of the three phylotypes may show a large seasonal and inter-annual variability, as has been shown by most of the temporal studies of estuarine foraminiferal faunas (e.g. Lutze, 1968; Wefer, 1976; Murray,
1983; Cearreta, 1988; Murray, 1992; Gustafsson and Nordberg, 1999; Murray and Alve, 2000; Korsun and Hald, 2000; Morvan et al., 2006; Horton and Murray, 2007; Papaspyrou et al., 2013; Saad and Wade, 2017; Richirt et al., 2020; Choquel et al., 2021). Although different species appear to show different reproduction and growth periods, this has not yet been demonstrated for the different Ammonia phylotypes. It is evident that temporal studies at a seasonal scale are needed to investigate this aspect. The presence of such putative seasonal or inter-annual differences between phylotypes will also inform us about their ecological preferences.

\subsubsection{Ecological niches}

The environmental conditions at local and regional scales favouring the three phylotypes will constitute a prerequisite for their settlement. However, at this time, no clear correlation between the distribution pattern (both at a regional scale and within single estuaries) of the three phylotypes and associated environmental conditions has emerged (Saad and Wade, 2016; Bird et al., 2020; present study). This highlights the fact that the controlling parameters of the distribution patterns of the different phylotypes are not well known yet and need to be studied in more detail, especially at their microhabitat scale.

\section{Conclusion}

The results of this study support the reliability of the morphometric method to distinguish between phylotypes T1, T2 and T6 of the genus Ammonia with an estimated accuracy of $\sim 96 \%$. This study represents the first large-scale application of the morphometric determination method to discriminate between the Ammonia phylotypes T1, T2 and T6. The combined morphological-molecular dataset presented here unveils the presence of a clear and coherent distribution pattern around the coastlines of the British Isles. The overall distribution pattern suggests that the supposedly invasive phylotype T6 progressively extends its distributional area and replaces the autochthonous T1 and T2 phylotypes. However, in the area where T6 is strongly dominant, phylotype T2 seems to subsist in refuges, positioned in higher and more inward parts of estuaries or marsh systems. The large-scale general distribution pattern suggests that the spreading of T6 in the English Channel may be slowed down or hampered by the presence of major biogeographical boundaries related to the dominant current patterns. Finally, the confirmation of the strong reliability of the morphometric determination method should allow us to work confidently on foraminiferal material, avoiding systematic molecular identification of specimens, which is both expensive and time-consuming. This will allow us to rapidly generate large datasets and thereby gain insight into the ecological differences between the three phylotypes. The morphometric analysis of sub-recent and/or fossil material, for which molecular study is still very dif- 
ficult, if not impossible, will allow us to study historical changes in distribution patterns (for instance due to changing anthropogenic pressure) and to verify the putative invasive character of phylotype T6.

Data availability. The data are available in the Supplement. Specimens from Saad and Wade (2016) and those measured in this study are available at the UMR 6112 LPG-BIAF Recent and Fossil BioIndicators Laboratory, University of Angers, France.

Supplement. The supplement related to this article is available online at: https://doi.org/10.5194/jm-40-61-2021-supplement.

Author contributions. SS, CW, FJ and VB performed the sampling (Saad and Wade, 2016, and AMTEP datasets). Genetic analyses were done by SQ and MS (AMTEP dataset). SEM images were performed by MS and JR. Morphometric analyses and statistics were done by JR. All authors contributed to the writing of the paper.

Competing interests. The authors declare that they have no conflict of interest.

Acknowledgements. This study has been partly financed by the CNRS/INSU programme EC2CO-LEFE. We are grateful to Romain Mallet and the team of the SCIAM imaging facility at the University of Angers for the SEM images. We gratefully acknowledge the help of many colleagues who provided samples.

Review statement. This paper was edited by Laia Alegret and reviewed by Bruce Hayward and one anonymous referee.

\section{References}

Alve, E.: Benthic foraminiferal responses to estuarine pollution; a review, J. Foramin. Res., 25, 190-203, https://doi.org/10.2113/gsjfr.25.3.190, 1995.

Alve, E. and Goldstein, S. T.: Dispersal, survival and delayed growth of benthic foraminiferal propagules, J. Sea Res., 63, 3651, https://doi.org/10.1016/j.seares.2009.09.003, 2010.

Bailly Du Bois, P. and Dumas, F.: TRANSMER, hydrodynamic model for medium- and long-term simulation of radionuclides transfers in the English Channel and southern North Sea, Radioprotection, 40, S575-S580, https://doi.org/10.1051/radiopro:2005s1-084, 2005.

Barnay, A., Ellien, C., Gentil, F., and Thiébaut, E.: A model study on variations in larval supply: are populations of the polychaete Owenia fusiformis in the English Channel open or closed?, Helgoland Mar. Res., 56, 229, https://doi.org/10.1007/s10152-0020122-2, 2003.
Bird, C., Schweizer, M., Roberts, A., Austin, W. E. N., Knudsen, K. L., Evans, K. M., Filipsson, H. L., Sayer, M. D. J., Geslin, E., and Darling, K. F.: The genetic diversity, morphology, biogeography, and taxonomic designations of Ammonia (Foraminifera) in the Northeast Atlantic, Mar. Micropaleosntol., https://doi.org/10.1016/j.marmicro.2019.02.001, 2020.

Bouchet, V. M. P., Debenay, J.-P., Sauriau, P.-G., RadfordKnoery, J., and Soletchnik, P.: Effects of short-term environmental disturbances on living benthic foraminifera during the Pacific oyster summer mortality in the MarennesOléron Bay (France), Mar. Environ. Res., 64, 358-383, https://doi.org/10.1016/j.marenvres.2007.02.007, 2007.

Bradshaw, J. S.: Laboratory Studies on the Rate of Growth of the Foraminifer, "Streblus beccarii (Linné) var. tepida (Cushman)", J. Paleontol., 31, 1138-1147, 1957.

Brunner, C. A. and Biscaye, P. E.: Storm-driven transport of foraminifers from the shelf to the upper slope, southern Middle Atlantic Bight, Cont. Shelf Res., 17, 491-508, https://doi.org/10.1016/S0278-4343(96)00043-X, 1997.

Brunner, C. A. and Biscaye, P. E.: Production and resuspension of planktonic foraminifers at the shelf break of the Southern Middle Atlantic Bight, Deep-Sea Res. Pt. I, 50, 247-268, https://doi.org/10.1016/S0967-0637(02)00165-6, 2003.

Calvo-Marcilese, L. and Langer, M. R.: Breaching biogeographic barriers: the invasion of Haynesina germanica (Foraminifera, Protista) in the Bahía Blanca estuary, Argentina, Biol. Invasions, 12, 3299-3306, https://doi.org/10.1007/s10530-010-9723$\mathrm{x}, 2010$.

Carstensen, J., Andersen, J. H., Gustafsson, B. G., and Conley, D. J.: Deoxygenation of the Baltic Sea during the last century, P. Natl. Acad. Sci. USA, 111, 5628-5633, https://doi.org/10.1073/pnas.1323156111, 2014.

Cearreta, A.: Population dynamics of benthic foraminifera in the Santoña estuary, Spain, Revue de Paléobiologie, 2, 721-724, 1988.

Choquel, C., Geslin, E, Metzger, E., Houliez, E., Jesus, B., Prins, A., Jauffrais, T., Bénéteau, E., and Mouret, A.: Spatiotemporal dynamics of living benthic foraminifera revealed by multiple environmental parameters and in situ trophic model in intertidal mudflat (Bourgneuf Bay, France), in preparation, 2021.

Cugier, P. and Le Hir, P.: Development of a 3D Hydrodynamic Model for Coastal Ecosystem Modelling. Application to the Plume of the Seine River (France), Estuar. Coast. Shelf S., 55, 673-695, https://doi.org/10.1006/ecss.2001.0875, 2002.

Dauvin, J., Rius, A. T., and Ruellet, T.: Recent expansion of two invasive crabs species Hemigrapsus sanguineus (de Haan, 1835) and H. takanoi Asakura and Watanabe 2005 along the Opal Coast, France, https://doi.org/10.3391/AI.2009.4.3.3, 2009.

Dauvin, J.-C.: Are the eastern and western basins of the English Channel two separate ecosystems?, Mar. Pollut. Bull., 64, 463471, https://doi.org/10.1016/j.marpolbul.2011.12.010, 2012.

Dauvin, J.-C.: History of benthic research in the English Channel: From general patterns of communities to habitat mosaic description, J. Sea Res., 100, 32-45, https://doi.org/10.1016/j.seares.2014.11.005, 2015.

Dupont, L., Jollivet, D., and Viard, F.: High genetic diversity and ephemeral drift effects in a successful introduced mollusc (Crepidula fornicata: Gastropoda), Mar. Ecol.-Prog. Ser., 253, 183-195, https://doi.org/10.3354/meps253183, 2003. 
Dupont, L., Ellien, C., and Viard, F.: Limits to gene flow in the slipper limpet Crepidula fornicata as revealed by microsatellite data and a larval dispersal model, Mar. Ecol.-Prog. Ser., 349, 125138, https://doi.org/10.3354/meps07098, 2007.

Ellien, C., Thiebaut, É., Barnay, A.-S., Dauvin, J.-C., Gentil, F., and Salomon, J.-C.: The influence of variability in larval dispersal on the dynamics of a marine metapopulation in the eastern Channel, Oceanol. Acta, 23, 423-442, https://doi.org/10.1016/S03991784(00)00136-5, 2000.

Fouet, M., Heliot, S., Singer, D., Barras, C., and Jorissen, F. J.: How to adapt foraminiferal index to estuaries? Application of the MII index, in preparation, 2021.

Geslin, E., Barras, C., Langlet, D., Nardelli, M. P., Kim, J.-H., Bonnin, J., Metzger, E., and Jorissen, F. J.: Survival, Reproduction and Calcification of Three Benthic Foraminiferal Species in Response to Experimentally Induced Hypoxia, in: Approaches to Study Living Foraminifera: Collection, Maintenance and Experimentation, edited by: Kitazato, H. and Bernhard, J. M., 163193, Springer Japan, Tokyo, https://doi.org/10.1007/978-4-43154388-6_10, 2014.

Gothland, M., Dauvin, J. C., Denis, L., Dufossé, F., Jobert, S., Ovaert, J., Pezy, J. P., Tous Rius, A., and Spilmont, N.: Biological traits explain the distribution and colonisation ability of the invasive shore crab Hemigrapsus takanoi, Estuar. Coast. Shelf S., 142, 41-49, https://doi.org/10.1016/j.ecss.2014.03.012, 2014.

Gustafsson, M. and Nordberg, K.: Benthic foraminifera and their response to hydrography, periodic hypoxic conditions and primary production in the Koljö fjord on the Swedish west coast, J. Sea Res., 41, 163-178, https://doi.org/10.1016/S13851101(99)00002-7, 1999.

Hayward, B. W., Holzmann, M., Grenfell, H. R., Pawlowski, J., and Triggs, C. M.: Morphological distinction of molecular types in Ammonia - towards a taxonomic revision of the world's most commonly misidentified foraminifera, Mar. Micropaleontol., 50, 237-271, https://doi.org/10.1016/S0377-8398(03)00074-4, 2004.

Hayward, B. W., Holzmann, M., and Tsuchiya, M.: Combined Molecular and Morphological Taxonomy of the Beccarii/T3 Group of the Foraminiferal Genus Ammonia, J. Foramin. Res., 49, 367-389, https://doi.org/10.2113/gsjfr.49.4.367, 2019.

Hemleben, C., Spindler, M., and Anderson, O. R.: Modern Planktonic Foraminifera, Springer-Verlag, New York, 363 pp., 1989.

Hermelin, J. O. R.: Distribution of Holocene benthic foraminifera in the Baltic Sea, J. Foramin. Res., 17, 62-73, https://doi.org/10.2113/gsjfr.17.1.62, 1987.

Holzmann, M.: Species Concept in Foraminifera: Ammonia as a Case Study, Micropaleontology, 46, 21-37, 2000.

Holzmann, M. and Pawlowski, J.: Molecular, morphological and ecological evidence for species recognition in Ammonia (Foraminifera), J. Foramin. Res., 27, 311-318, https://doi.org/10.2113/gsjfr.27.4.311, 1997.

Holzmann, M. and Pawlowski, J.: Taxonomic relationships in the genus Ammonia (Foraminifera) based on ribosomal DNA sequences, J. Micropalaeontol., 19, 85-95, https://doi.org/10.1144/jm.19.1.85, 2000.

Holzmann, M., Piller, W., and Pawlowski, J.: Sequence variations in the large-subunit ribosomal RNA gene of Ammonia (Foraminifera, Protozoa) and their evolutionary implications, J.
Mol. Evol., 43, 145-151, https://doi.org/10.1007/BF02337359, 1996.

Horton, B. P. and Murray, J. W.: The roles of elevation and salinity as primary controls on living foraminiferal distributions: Cowpen Marsh, Tees Estuary, UK, Mar. Micropaleontol., 63, 169-186, https://doi.org/10.1016/j.marmicro.2006.11.006, 2007.

Jones, R. W.: Foraminifera and their Applications, Cambridge University Press, New York, 391 pp., 2014.

Katz, M. E., Cramer, B. S., Franzese, A., Hönisch, B., Miller, K. G., Rosenthal, Y., and Wright, J. D.: Traditional and emerging geochemical proxies in foraminifera, J. Foramin. Res., 40, 165192, https://doi.org/10.2113/gsjfr.40.2.165, 2010.

Korsun, S. and Hald, M.: Seasonal dynamics of benthic foraminifera in a glacially fed fjord of Svalbard, European Arctic, J. Foramin. Res., 30, 251-271, https://doi.org/10.2113/0300251, 2000.

Kuhnt, T., Howa, H., Schmidt, S., Marié, L., and Schiebel, R.: Flux dynamics of planktic foraminiferal tests in the south-eastern Bay of Biscay (northeast Atlantic margin), J. Marine Syst., 109_ 110, S169-S181, https://doi.org/10.1016/j.jmarsys.2011.11.026, 2013.

Langer, M. and Leppig, U.: Molecular phylogenetic status of Ammonia catesbyana (D’Orbigny, 1839), an intertidal foraminifer from the North Sea, Neues Jahrb. Geol. P. M., 9, 545-556, https://doi.org/10.1127/njgpm/2000/2000/545, 2000.

Larsonneur, C., Bouysse, P., and Auffret, J.-P.: The superficial sediments of the English Channel and its Western Approaches, Sedimentology, 29, 851-864, https://doi.org/10.1111/j.13653091.1982.tb00088.x, 1982.

Lefebvre, A., Ellien, C., Davoult, D., Thiébaut, E., and Salomon, J. C.: Pelagic dispersal of the brittle-star Ophiothrix fragilis larvae in a megatidal area (English Channel, France) examined using an advection/diffusion model, Estuar. Coast. Shelf S., 57, 421-433, https://doi.org/10.1016/S0272-7714(02)00371-2, 2003.

Lutze, G. F.: Jahresgang der Foraminiferen-Fauna in der Bottsand-Lagune (westliche Ostsee), MEYNIANA, 18, 13-20, https://doi.org/10.2312/meyniana.1968.18.13, 1968.

Morard, R., Vollmar, N. M., Greco, M., and Kucera, M.: Unassigned diversity of planktonic foraminifera from environmental sequencing revealed as known but neglected species, PLOS ONE, 14, e0213936, https://doi.org/10.1371/journal.pone.0213936, 2019.

Morvan, J., Debenay, J.-P., Jorissen, F., Redois, F., Bénéteau, E., Delplancke, M., and Amato, A.-S.: Patchiness and life cycle of intertidal foraminifera: Implication for environmental and paleoenvironmental interpretation, Mar. Micropaleontol., 61, 131154, https://doi.org/10.1016/j.marmicro.2006.05.009, 2006.

Murray, J. W.: Population dynamics of benthic foraminifera; results from the Exe Estuary, England, J. Foramin. Res., 13, 1-12, https://doi.org/10.2113/gsjfr.13.1.1, 1983.

Murray, J. W.: Distribution and population dynamics of benthic foraminifera from the southern North Sea, J. Foramin. Res., 22, 114-128, https://doi.org/10.2113/gsjfr.22.2.114, 1992.

Murray, J. W.: Ecology and Applications of Benthic Foraminifera, Cambridge University Press, Cambridge, 426 pp., 2006.

Murray, J. W. and Alve, E.: Major aspects of foraminiferal variability (standing crop and biomass) on a monthly scale in an intertidal zone, J. Foramin. Res., 30, 177-191, https://doi.org/10.2113/0300177, 2000. 
Papaspyrou, S., Diz, P., García-Robledo, E., Corzo, A., and Jimenez-Arias, J.-L.: Benthic foraminiferal community changes and their relationship to environmental dynamics in intertidal muddy sediments (Bay of Cádiz, SW Spain), Mar. Ecol.-Prog. Ser., 490, 121-135, https://doi.org/10.3354/meps10447, 2013.

Pawlowski, J. and Holzmann, M.: Diversity and geographic distribution of benthic foraminifera: a molecular perspective, Biodivers. Conserv., 17, 317-328, https://doi.org/10.1007/s10531007-9253-8, 2008.

Pawlowski, J., Bolivar, I., Farhni, J., and Zaninetti, L.: DNA analysis of "Ammonia beccarii" morphotypes: one or more species?, Mar. Micropaleontol., 26, 171-178, https://doi.org/10.1016/0377-8398(95)00022-4, 1995.

Petersen, J., Riedel, B., Barras, C., Pays, O., Guihéneuf, A., Mabilleau, G., Schweizer, M., Meysman, F. J. R., and Jorissen, F. J.: Improved methodology for measuring pore patterns in the benthic foraminiferal genus Ammonia, Marine Micropaleontol., 128, 1-13, https://doi.org/10.1016/j.marmicro.2016.08.001, 2016.

Polovodova, I., Nikulina, A., Schönfeld, J., and Dullo, W.C.: Recent benthic foraminifera in the Flensburg Fjord (Western Baltic Sea), J. Micropalaeontol., 28, 131-142, https://doi.org/10.1144/jm.28.2.131, 2009.

Richirt, J., Schweizer, M., Bouchet, V. M. P., Mouret, A., Quinchard, S., and Jorissen, F. J.: Morphological distinction of three Ammonia phylotypes occurring along european coasts, J. Foramin. Res., 49, 77-94, https://doi.org/10.2113/gsjfr.49.1.76, 2019a.

Richirt, J., Champmartin, S., Schweizer, M., Mouret, A., Petersen, J., Ambari, A., and Jorissen, F. J.: Scaling laws explain foraminiferal pore patterns, Sci. Rep.-UK, 9, 9149, https://doi.org/10.1038/s41598-019-45617-x, 2019b.

Richirt, J., Riedel, B., Mouret, A., Schweizer, M., Langlet, D., Seitaj, D., Meysman, F. J. R., Slomp, C. P., and Jorissen, F. J.: Foraminiferal community response to seasonal anoxia in Lake Grevelingen (the Netherlands), Biogeosciences, 17, 1415-1435, https://doi.org/10.5194/bg-17-1415-2020, 2020.

Saad, S. A. and Wade, C. M.: Biogeographic distribution and habitat association of Ammonia genetic variants around the coastline of Great Britain, Mar. Micropaleontol., 124, 54-62, https://doi.org/10.1016/j.marmicro.2016.01.004, 2016.

Saad, S. A. and Wade, C. M.: Seasonal and Spatial Variations of Saltmarsh Benthic Foraminiferal Communities from North Norfolk, England, Microb. Ecol., 73, 539-555, https://doi.org/10.1007/s00248-016-0895-5, 2017.
Salomon, J.-C. and Breton, M.: An atlas of long-term currents in the channel, Oceanol. Acta, 16, 439-448, 1993.

Schönfeld, J., Alve, E., Geslin, E., Jorissen, F., Korsun, S., and Spezzaferri, S.: The FOBIMO (FOraminiferal BIo-MOnitoring) initiative - Towards a standardised protocol for soft-bottom benthic foraminiferal monitoring studies, Mar. Micropaleontol., 9495, 1-13, https://doi.org/10.1016/j.marmicro.2012.06.001, 2012.

Schweizer, M., Jorissen, F., and Geslin, E.: Contributions of molecular phylogenetics to foraminiferal taxonomy: General overview and example of Pseudoeponides falsobeccarii Rouvillois, 1974, C. R. Palevol., 10, 95-105, https://doi.org/10.1016/j.crpv.2011.01.003, 2011a.

Schweizer, M., Polovodova, I., Nikulina, A., and Schönfeld, J.: Molecular identification of Ammonia and Elphidium species (Foraminifera, Rotaliida) from the Kiel Fjord (SW Baltic Sea) with rDNA sequences, Helgoland Mar. Res., 65, 1-10, https://doi.org/10.1007/s10152-010-0194-3, 2011 b.

Schweizer, M., Richirt, J., Quinchard, S., Jauffrais, T., Laenger, A., Garnier, J., Saur, H., Toyofuku, T., Pawlowski, J., Jorissen, F. J.: Distribution of intertidal Ammonia phylotypes (Foraminifera, Rhizaria) along the European coasts and beyond, in preparation, 2021.

Sen Gupta, B. K.: Introduction to modern Foraminifera, in: Modern Foraminifera, edited by: Sen Gupta, B. K., Kluwer Academic Publisher, Dordrecht, 3-6, 2003.

Wefer, G.: Umwelt, Produktion und Sedimentation benthischer Foraminiferen in der westlichen Ostsee, $\mathrm{PhD}$ thesis, University of Kiel, Germany, 1976.

Weiner, A. K. M., Morard, R., Weinkauf, M. F. G., Darling, K. F., André, A., Quillévéré, F., Ujiie, Y., Douady, C. J., de Vargas, C., and Kucera, M.: Methodology for SingleCell Genetic Analysis of Planktonic Foraminifera for Studies of Protist Diversity and Evolution, Front. Mar. Sci., 3, 255, https://doi.org/10.3389/fmars.2016.00255, 2016.

Wolff, W. J. and Reise, K.: Oyster Imports as a Vector for the Introduction of Alien Species into Northern and Western European Coastal Waters, in: Invasive Aquatic Species of Europe. Distribution, Impacts and Management, edited by: Leppäkoski, E., Gollasch, S., and Olenin, S., 193-205, Springer Netherlands, Dordrecht, https://doi.org/10.1007/978-94-015-9956-6_21, 2002. 